INTERNATIONAL JOURNAL OF RESEARCHES IN BIOSCIENCES, AGRICULTURE AND TECHNOLOGY (C) VISHWASHANTI MULTIPURPOSE SOCIETY (Global Peace Multipurpose Society) R. No. MH-659/13(N) www.vmsindia.org

\title{
STUDIES ON POLLEN STORAGE AT DIFFERENT TEMPERATURE AND HUMIDITY CONDITIONS IN ORYZA SATIVA L.
}

\author{
A. A. Saoji ${ }^{1}$ and K. G. Rewatkar ${ }^{2}$ \\ ${ }^{1}$ Institute of Science, Nagpur \\ ${ }^{2}$ Dr. Ambedkar College, Nagpur \\ kgrewatkar@gmail.com
}

\begin{abstract}
Oryza sativa L. (Rice) belongs to family poaceae is annual grass. The pollen grains of this plant are short lived. In the course of plant breeding, pollen serves as a powerful means in establishing genetic bases that lead to new cultivars, as also to improve the existing one. The experimental results reveal that the pollen grains of some varieties could be well presented for a period of 20 days at high relative humidity $(\mathrm{RH})$ and low temperature $(3 \mathrm{oC})$. The germinabilit of pollen was observed to be good upto 6 th day of storage and during the remaining days there appears to be slow decline in the geminiability of stored pollen grains.
\end{abstract}

Keywords: Pollen grains, RH, Oryza sative, Germination, low temperature,

\section{Introduction:}

Oryza sativa L. is an important cereal and staple food of more than half of the world's population. Rice grain contains protein $6.9 \%$, fat $0.4 \%$, carbohydrate $79.2 \%$ mineral mater and other elements in micrograms. The rice grains are directly used as food after boiling. Other rice products of commercial importance are parched rice (mumura), beaten rice (poha) and parched paddy (lahi). Alcoholic beverages are prepared from rice after fermentation. Rice plant is an annual grass with round hallow jointed culm. Inflorescence is lax, erected, terminal panicle i.e. group of spikelets. Flowring occurs about 25 days after booting pollen ghrains a 3-celled and short lived; so it is very essential to increase their viability for longer time. The importance of pollen storage in plant breeding programme is well known.

\section{Material and Methods:}

Polleniferous material of some varieties of oryza sativa was collected soon after the anthesis i.e. between 9 am to $11 \mathrm{am}$. In order to avoid discrepancies, pollen from different anthers of a single flower were used after thorough mixing pollen grains were store a room temperature and at $3 \mathrm{oC}$ in refrigerator 0,10 , 20,30, 40, 60, 80 and $100 \% \mathrm{RH}$ level. The desired RH levels were maintained in desiccators using different concentration of sulphuric acid [1]. Pollen grains were transferred into small glass vials which were loosely closed with cotton plugs and kept in desiccators maintained at different $\mathrm{RH}$ levels at room temperature and 3oC. Viability was tested by germinating the stored samples in $5 \%$ sucrose solution using "standing drop" technique at regular intervals.

\section{Result and Discussion:}

Graph-I represents the percentage of germination of stored pollen grains at room temperature under various humidity level at successive intervals of storage period. It is cleared that the pollen grains of Oryza sativa can be stored and their viability can be prolonged for 3 days at room temperature witah high RH levels varying from 60 to $100 \%$. Out of these $80 \%$ RH was found to be the best. Graph II (table -2) indicates the viability of pollen grains stored at low temperature i.e. 3oC could be prolonged for 20 days and better viability percentage was obtained that at room temperature. Maximum germination was $58.38 \%$ with a tube length of $289.65 \mu \mathrm{m}$ was seen on the 6th day of storage at $80 \%$ RH. Pollen storage conditions that maintain fertility increase the efficiency of handling breeding and genetic material of any plant species [2]. A systemic study on the storage of pollen was initiated towards the end of nineteenth century Roemer (1915) [3] found that pollen storage at low temperature preserved germination capacity better than high temperature. Hoekstra and Bruinsma (1975 b) [4] are of the opinion that increased respiration is the cause for the loss of viability in three-celled pollen. Pollen of some grasses remains viable only for a few days when stored at 0oC-10oC and 80-100\% RH (Pfund 1910 [5], Andronescu 1915 [6]). Visser et al (1977) [7] is of the opinion that the humidification is necessary for the stored pollen grains since due to continuous dehydration, the pollen wall tends to lose its flexibility. Pollen grains of graminaceous taxa lose viability very rapidly successful storage was thought to be limited to only about ten days under best 
storage condition (Srivanna and Johri 1985) [8]. However Li Xun Zhen et al (1996) [9] stored rice pollen grains at low temperature for 15 days. In present study pollen grains of some varieties of Oryza sativa showed maximum viability at $80 \%$ $\mathrm{RH}$ and prolonged its germinability for 20 days.

\section{Conclusion:}

In present study pollen grains of some varieties of Oryza sativa showed maximum viability at $80 \% \mathrm{RH}$ and prolonged its germinability for 20 days.

\section{Reference:}

1. Wilson R.E. (1921): Humidity control by means of sulphuric acid solution with critical complication of vapour pressure data, J. Industr. Engg. Chem. 13 : 326-331

2. Rodriguez- Garay and Barrow (1986): short term storage of cotton pollen. Plant Cell Reports $5: 332-333$.

3. Roemer T. (1915): Zur Pollenaufberoahrung. Zeits pflanzenz. $2: 83-86$
4. Hoekstra F.A., Bruinsma J. (1975 b): Respiration and viability of binucleate and trinucleate pollen. Physiol. Plant 34 : 221-225.

5. Pfundt $M$ (1910): Der Einfluss der Luftfeuchtigkeit auf die Lebensdauer des Blutenstaubes Jahrb. Wiss Bot. 47 : 1-47.

6. Andronescu D. I. (1915): The physiology of the pollen of Zea mays with special regards to viability. Ph.D. thesis, Univ. Illinois, USA.

7. Vissser T, De Vries, Weller D. P. And Scheurink G. W. H. (1977): Hybrid Storage Ephytica, 26: 721-728.

8. Shivanna K.R. and John B.M (1985): The Angiosperm Pollen structure and Function. Willey Eastern Limited, New Delhi, India.

9. Li Xun Zhen, Zhou Guang Qui, Xu Meng Liang, Chen Liang Bi, Huang Chong Qe, Huang He Qing (1996): Effect of mechanical collection and pollination of rice pollen on the vigor and seed set in hybridization. Acta Agronomica Sinica, 22 (3): 353-357. 